\title{
THE ROLE AND BEHAVIOR OF THE INDIVIDUAL IN THE DEVELOPMENT OF SOCIAL CAPITAL
}

\author{
Natalia Riabinina ${ }^{1}$
}

\begin{abstract}
At the intersection of the past and the future there is a point of present, which, due to external and internal socio-economic requirements, activates the subject himself, when uniting the sciences of economics and sociology, as well as psychology, philosophy and law, we see the development of a new scientific direction - social capital. Interdisciplinary and multi-vector methodological conception on development has the capabilities to use in all spheres of life, to develop a more productive and inclusive economy because it works directly with people and for people. The development of society and the formation of institutions of citizenship and economic growth are inherently connected with the new economic and social concept, which is an incentive for self-organization, and the establishment of interpersonal and intergroup relations, leading to a path of harmonization based on sincere help and trust. Formulation of the goals and objectives of the article (setting a task). A large amount of research on social capital, a wide and diverse direction of study directly inhibits the systemicity and orderliness of concepts and theoretical knowledge, so at the beginning of the study it is necessary to put problems, tasks, a place in the knowledge system and connection with other disciplines. The purpose of the study is to separate and determine the individuality of a person in the process of social capital, attitude and behavior of the individual and group at all levels of this concept, analysis, specifics and structural content of social capital.

Methodology. During the research, to study and achieve the goal, the analysis of theoretical aspects and generalizations of scientific sources, dialectic cognition of the formation of social capital, revealed a kind of economic concept, methods of induction and deduction, abstraction of theoretical provisions and dialectic cognition were carried out. Results. The article raises the issue of the resource of socio-economic growth and improvement, on the basis of intergroup and interpersonal interactions and relationships at a high micro level, on the foundation of trust and cooperation between people, single work and development of state, economic, civic platforms. It is with humans that the mechanism of development, accumulation and effective use begins. The accumulation of individuality in the development of social capital of the economic system and the main components of social capital, such as trust and reliability, are studied. The analysis of economic behavior of the individual when making a rational decision in the world of economic changes is carried out. The practical component of the main provisions of the concept and levels of social capital, and its role in the general concept of the economic component can further develop and be used in the process of developing the analysis and development of the individual with individual behavior and personal decision-making. Value/originality. The theory of social capital itself is new and little-studied, so any vector of study and research gives a new impetus to interest and further development of the detection of theoretical aspects, generalization to definition and essence, outlining the main directions of development and formation for the future.
\end{abstract}

Key words: social capital, social structures, interconnection and interaction, network society.

JEL Classification: M15, A14, O35, D71

\section{Introduction}

For decades, scientists of economics and sociology have been working on the study of various directions, but economic behavior, economic activity, economic relations of a person are studied quite a little, which allows to consider

Corresponding author:

${ }^{1}$ University of the State Fiscal Service of Ukraine, Ukraine.

E-mail: riabininano@gmail.com

ORCID: https://orcid.org/0000-0001-8378-4485 the relationship and mutual conditionality of consciousness and behavior (activity) of an economic entity (individual), claiming the variant and diversity of individual and group differences between subjects and the spread of coordination or contradiction of meaningful characteristics 
of economic consciousness and behavior. At the end of the last century, geopolitical factors, difficulties in creating market relations, financial crises, neglect of local and national institutions, contributed to the impetus for recognizing the problems of correctness of social and economic decisions.

The study and interest in the social dimensions of development in general and the idea of social capital is deeply explored quite recently, but the roots of the idea of interdisciplidary direction are in the middle of the last century. The theoretical foundations of social capital and a look at the empirical evidence of recent research lead to the confirmation of key hypotheses regarding the feasibility and necessity of the development of multi-vector economic science, economic development in the social direction and the relationship between informal and formal institutions for the ability to manage and operetta risks and lead to economic growth and prosperity.

Over the past decade, we have seen a revival of interest in the social and institutional dimensions of economic development, which carries a proactive and positive contribution, increasingly focusing on the national and ethnic characteristics of a particular region. There are many fundamental, theoretical and methodological issues that arise during the intensive development of science, so the new academic discipline is becoming increasingly in demand in education, in particular, in terms of training specialists in economics and sociology. The Nobel Laureate Douglas North (1990) contributed to the understanding and significance of economic indicators with their rules, consistence and regulatory instruments, although the first to direct the interest of scientists and reveal the boundless possibilities and necessity of studying social capital was James Coleman (1988). "Social capital, like expanding networks or social contacts, has a beneficial effect on a person's economic achievements" or "relationships between participants, as well as resources that go through the connections that bind them" (Coleman 1990). Political scientist Robert Putnam (1993) showed that the work of a wide network of public and economic associations helped develop information and social trust that carries "features of social organization such as networks, norms and social trust that promote coordination and cooperation for mutual benefit" (Putnam 2000). Sociologist Peter Evans (1992, 1995) raised the issue of relations between the state and society. Fukuyama (1993) applied social connections and networks for management decisions and social development, focusing on the trust and reliability of partners. "Social capital is a certain potential of society or its part, which arises as a result of the presence of trust between its members. It can be embodied in the smallest basic social group - family, and in the largest team of possible - the nation" (Fukuyama, 2008). All these studies have become contributions to the development of the theory of social capital, to this day intriguing integration in economics and sociology.

\section{The concept of "social capital"}

Unfortunately, the theory of social capital is not the only one, having different interdisciplinary approaches and different points of view of concepts and concepts, raising to the surface differences in research directions and levels of concept analysis. What is social capital? This is the benefit of communication, and in the economic sphere the benefits of production and entrepreneurial, arising from the possibility of combining and finding new solutions, in joint and generous thinking and actions based on mutual respect, trust and mutual understanding, including good and open will and solidarity between people or groups. In this case, the term "capital" has ontological meaning and is used to reflect reality, the sphere of human existence, social life, phenomenology and the problems of which is based on the field of economic life. Any level of economic life of society requires a separate approach to study and analysis from a social and psychological point of view. The system of social processes of production, exchange, distribution and use of material and spiritual benefits, relations between business entities originate from a separate individual, small groups (family, firms), growing to large social categories (organization, enterprise, ethnic group, state).

Wisdom, "it's not what you know, it's what you know" clearly gives an idea of the basics of social capital. Each person, at least once in his life, in difficult situations or in joy, uses this aphorism. A wide range of friends and communication with colleagues, family support, conversations with neighbors, religious meetings or volunteering, correspondence in the chad, relationships with business partners or a separate project makes it possible to start and further movements in decision- 
making for the future. By uniting, "communities are endowed with a rich supply of social networks, and community associations will be in a stronger position to confront poverty and vulnerability" (Moser 1996; Narayan, 1997) to implement new innovative trends and opportunities for the development of inclusive development of today. One of the main features of poverty is the lack or small activity of communication, the relationship in the family, institution, social networks, at work, rest. Social capital may require liability with costs, and may bear benefits with future assets, may be a boon and vice versa hacking.

\section{Level of social capital}

It is possible to give the shape of the social capital on the macro-storm, meso-that microregion. Macrolevel will expand on the power scale, the need for a burden of social groups, macro-economic realitys: the economic police, the good-natured power of the forest. The main platform is the sphere of the economy in the same way that the suspense. The characteristics of the representatives of the great social-environmental groups (p.d., services, naimatets, non-thorough, non-professional, non-psychological groups), that ekonom-psychological characteristics of the broad social group (ethn.com, demography). At this level, the mechanisms of economic behavior of citizens in relation to the state, social problems, attitude to property, inflation, unemployment, shadow economy, wealth and poverty are widely highlighted. The social mesorium examines individual enterprises and firms, the population of specific regions, with their socio-economic peculiarities and directly examines the field of business from the middle. Referrals to individual individuals and small groups, where empirical research is set up for a family, the economic behavior of an individual or a small group in a beat, revealing the problems of demand, preservation, decision-making on family budgets, economic socialization of children in the family, relationships and interactions between the seller and the buyer, the tax service official and the taxpayer, is not the whole list of issues that the microsocial level poses.

\section{Social capital and personality}

There is still no unified concept of levels of social capital analysis in the direction of communication and interaction. At the level of personality, attention is often focused on the analysis of a person in social networks and their characteristics of relationships, organization, community or group focus on social structures, norms and rules, and the level of society is based on public norms, reliability, trust, membership in associations, volunteering, etc. Recently, humanity has become more dependent on technological progress, innovative technological directions of electric and social networks and institutions, making itself more manager, and this is used by social media giants, denying access to resources. More and more research accounts for relationships, strategies for relationships between firms and enterprises in the fields of finance, technology and software that contribute to economic development against the backdrop of the technical revolution, although interest in households and communities at the micro level, based on the nature and scope of public initiative and information exchange, remains on time.

The topic of social capital is paid enough attention internationally, it was the World Bank (2003) that proposed six areas and dimensions of social capital that are used in scientific research and are more often taken as a basis: groups and networks, trust and solidarity, collective action and cooperation, information and communication, social cohesion and inclusion, empowerment and political activities (World Bank, 2003).

Social capital is sometimes confused with human capital, the term of which appeared in the economy earlier and carries information about the individual, in turn, social capital is based on the study of relations between people and society, so they complement and interact with each other, offering knowledgeable and competent people better to organize work, evaluate conflicting information and make the right decision, discuss an innovative project and express their suggestions and opinions. Each participant in the process, raising their self-esteem of efficiencies and responsibilities to the environment, focuses on achieving common decisions and goals, increasing and enering collective efficiency and action. "Common identity means recognition and commitment to the common good, as well as a willingness to sacrifice some personal interests for the sake of "we" - a group, community or society" (Belyaeva, 2019). One's aspirations, dreams, and goals give the individual a sense of 
unity, solidarity, and a spirit of unity, assuming one whole and meaningful with others, bringing benefits. "It inspires a sense of belonging and solidarity, as well as a feeling that others are "one of us" that facilitates trust and cooperation" (Syu i Hung, 2013). Acceptance and membership in the group's native thoughts and goals, emotional significance and desire for social identity, with their own rules, norms and values, acceptable behavioral models, responsibilities and expectations, history and language are of great importance to a person. "Membership provides access to many benefits, such as social support, access to resources and opportunities to improve our personal and social standing" (Tsanakis, 2013), although sometimes we observe inflections of the cohesion of like-minded people and the obsession of their ideas to society, which limits actions and development, inhibition of innovation and creativity.

\section{Aspect of economic science}

In economic science, interest and interest in social capital is traced not only by the presence of social networks and relationships, personal behavioral qualities of a person, such as trust, reciprocity, social attitudes and skills, tolerance, cooperation. as well as large-scale institutional measures that bear legal and public responsibility to society, social opportunities, cohesion, social infrastructure that helps to measure and develop this type of multi-vector capital. Consequently, social capital refers to social networks and norms that promote collective development and "any definition of social capital should focus on its sources, not on the consequences, on what it is, not on what it does" (Edwards and Foley, 1997). For example, trust we view as a measure, and invest in networks and social institutions that we trust, rather than treating it as a measure in itself. Therefore, the dimension of social capital is much more complex and diverse: structural, cognitive and relational, combining and complementing each other, recognizing the multidimensionality of sources, based on the vertical.

The main goal of specialists in the development of society is to overcome poverty, using resources, ideas and information from all possible directions, reducing the functions of rejection and powerlessness, without giving up the role of the state. "A distinctive feature of the approach to social capital is its approach to understanding poverty. Living on the verge of existence, the social capital of the poor is the asset they can potentially get, seek help negotiating a path through an unpredictable and relentless world. The very poor have "something to lose", namely each other" (Dordic, 1997) The concept of the importance of social relations becomes paramount, focusing on the strategic choice of rationality, with different budgetary, legal, time and other restrictions.

\section{Trust and reliability - the basis of social capital}

Trust and reliability are at the heart of social capital, a necessary component of the whole concept, because without them the effectiveness of a collective initiative cannot exist, allowing to find points of intersection in peaceful and stable ways of social relations, which is a platform for collective behavior and fruitful cooperation. "Trust is vital for any form of social interaction or exchange, and reliability "lubricates social life" (Cherty, 2008). Multi-vector economic activity requires at least minimal trust, which carries confidence and expectation of fulfillment of duties and agreements between people and society. Trust can be between people who know each other well, more often, such relationships are reliable and strong, situational and specific in circumstances relational to social capital, and trust between strangers is based on inclination and beliefs, providing a generalized, social and "thin" thread of trust. When we consider a particular person's behavior, we analyze the fulfillment of duties and promises, honesty, refusal of fraud and exploitation, and relationships with others are based on general norms and ideas. "As a rule, social trust should not be ignored, since there is evidence that social trust affects trust in relationships" (Robbins, 2016). The state and institutions play an important role in the perception of trust and reliability in society, developing common norms, rules and common understanding, reproducing and creating common ideas of this concept, preventing vulnerability and building reliability. "From some theoretical points of view, trust can be seen as accepting the risk and vulnerability associated with the actions of others, and the expectation that the other will not take advantage of this vulnerability" (Perdue, 2001). 


\section{Social relations and interaction of people in the economy}

Economic behavior and relationships are separated from the general sphere of human activity, proving the breadth of the study of the problem and the unlimited field of activity in the study of economic or socio-psychological phenomena of each individual. But you can look at the problem from a different point of view, based on the study of human activity, traditional problems, phenomena, subjects of psychology, and then the question will be interpreted differently: what role and degree of human behavior and relationships between people are recognized as economic factors, or how economic factors affect the formation of the individual, the nature of the person and the relationship between them, considering a person in the economic space as an external factor.

Studies of social components, separate from economic ones, have the opportunity to exist and study by choosing a direction for analysis and development: studying the impact of economic factors on social perception and behavior of subjects, the impact of the socio-psychological factor on economic behavior and relationships. Analyzing the relationship and the mutual impact of economic and social phenomena can not be separated only by two components, but it is necessary to expand the horizons of different levels (ethnocultural, socio-demographic, political and others), including in the modern general process of social life and interaction. All this is combined in the social capital, which is a complex applied branch of economic science that studies sociopsychological patterns of economic activity (economic representation, behavior, interaction of personal or group actors), interconnection and mutual impact of economic and social phenomena, promoting the development, replacement and effective use of missing and limited resources, using new skills, knowledge and skills, creating prerequisites for the development of personality, groups, society. "Social capital is not only an integral condition for the development of a capable society, but also its resource, which gives an opportunity and impetus to personal development to every citizen, restoration of trust between individuals and public authorities, as well as the ability and desire to participate in the work of state institutions." (Ore, Nagorna, 2020) Structuring social capital and identifying issues in parallel passes with the main areas of economic activity and their economic directions of behavior of personal or group entities: industrial, entrepreneurial, preservation, demand and others.

\section{Conclusion}

The term "social capital", built from two separate categories and has not only gnoséological, but also ontological understanding. The first term is used as the definition, disclosure and description of subjective reality in the world of social phenomena, reflecting the behavior and relationships of people, and the second as a real factor of social human existence and life in modern times. The relationship and interaction of economic and social combinations can be quite diverse, deep and wide, and therefore go beyond maternal disciplines, which leads to the independence of scientific direction. When creating new forms of social interactions and systemic structures of social relations, the information society focuses on the mechanisms of social partnership as a necessary element of social ties. In order to achieve gradual and consistent changes for the better, to improve the well-being of citizens, to create new democratic institutions, to build civil society, despite various interests, expectations, moods in different social groups in a market economy and a democratic society, social partnership acts as a personal direction of the state's activity, which creates a plane of new socio-economic relations at the present stage.

The desire to be in a social context requires us to recognize that people are a social product formed by social influence and the trend of our time. Social life in organizations also includes intergroup relationships and human social benefits together with group membership, and we should not forget that all this happens in the context of social processes at the level of a wider society.

\section{References:}

Belyaeva, L. A. (2019). Social capital: problematic field and empirical issledovanyia. Ecoconomic and social submenu, 64, 154-166.

Cherty, M. (2008). The paradoxes of the social capack: the invictus of the invictus of the Moroccans in London. The outreach of the Amsterdam University. 
Coleman, J. S. (1988). Social Capital in the Creation of Human Capital. The American Journal of Sociology, 94, S95.

Coleman, J. S. (1990). Foundations of social theory. Cambridge: Harvard University Press.

Dordick, Gwendolyn (1997). Something Left to Lose: Personal Relations and Survival Among New York's Homeless (Philadelphia, PA: Temple University Press).

Evans, P. B. (1993). Bilateral Diplomacy: International Trade and Domestic Politics, edited by Harold K. Jacobson and Robert Putnam. Available at: https://ru.qaz.wiki/wiki/Peter_B._Evans

Evans, P. B. (1995). Instronnaya Autonation: Statehood ahd Advanced Transformation. Available at: https://ru.qaz.wiki/wiki/Peter_B._Evans

Edwards, Bob, and Michael, Foley (1997). "Social Capital and the Political Economy of Our Discontent". American Behavioral Scientist, 40(5), 669-678.

Fukuyama, F. (2008). Doverye: socialist benefacies and the way of blooming. Moscow: AST.

Moser, Caroline (1996). Confronting Crisis: A Comparative Study of Household Responses to Poverty and Vulnerability in Four Poor Urban Communities (Washington, DC: The World Bank).

Narayan, Deepa (1997). "Voices of the Poor: Poverty and Social Capital in Tanzania" ESSD Studies and Monographs Series, vol. 20 (Washington, DC: The World Bank).

Narayan, Deepa, and Lant, Pritchett (1999). "Cents and Sociability: Household Income and Social Capital in Rural Tanzania” Economic Development and Cultural Change, 47(4), 871-897.

North, D. C. (1997). Institutes, institutional change and functioning of the economy. Institutions, Institutional Change and Economic Performance. Moscow: Foundation for Economic Book Beginnings. Perdue, D. (2001). Sosedskoye stewardship: hypocrisy, doverye and social capital. Horods'k issledovanyia, 38(12), 2211-2224.

Putnam, R. D. (1993). The prosperous community. The American Prospect, 4(13), 35-42.

Putnam, R. D. (2000). Bowling alone: the collapse and revival of American community. New York: Simon \& Schuster.

Robbins, B. G. (2016). Here's a common one: how socially perfect motivating is complete in the otnosheny. Research in the areas of social sciences, 55, 16-30.

Ruda, T. V., \& Nagorichna, O. S. (2020). The oretical aspects of formation of social capital in Ukraine. Innovative economy, 3-4. Available at: https://docs.google.com/viewerng/viewer?url= http://inneco.org/index.php/innecoua/article/viewFile/571/636

Syu, A. O., and Hung, Y. V. (2013). Izuchenye effektov recipitation of social kapital. Information and management, 50(7), 415-430.

Tsanakis, M. (2013). Socialist capital in the theory of Burdye, Coleman and Putnema: empirical data and ascension problems of ezymereny, 13(2), 2-23.

World Development Report (2003). Sustainable development in a changing world is transforming institutions, growth and quality of life. (Building based on traditional social capital) Issued for the World Bank. Publishing "All The World" Moscow 2003 (C) 2003 International Bank for Reconstruction and Development / World Bank 1818 H Street, N.W., Washington, D.C. 20433, U.S.A. (C) 2003 Translation Publishing "All World". Available at: http://documents1.worldbank.org/curated/ en/769361468151776514/pdf/247050WDR0RUSSIAN0Box370078B00PUBLIC0.pdf 